\title{
Preserving the Cultural Landscape Heritage of Bhimakali Temple and its surroundings, Sarahan, Himachal Pradesh, India
}

\author{
Excellent Hansda \\ Student of B. Arch, Department of Architecture E Planning, Indian Institute of Technology \\ Roorkee. ORCID: oooo-0oo3-4938-9945.Email: ehansda@ar.iitr.ac.in
}

\begin{abstract}
Bhimakali Temple Complex is a popular tourist attraction in the Shimla Hills. The temple complex and the dwellings surrounding are an interesting example of an architecture style developed based on the local constraints of the area. Nearly 800 years earlier, a palace was built housing a temple, by the king of the Bushahr Dynasty in Sarahan, a small town in Shimla District. Along with time, buildings were made around it and a village came up. The landscape which was once barren turned into a lively cultural landscape through a self-sustainable approach one. While the tangible heritage of monumental architecture of the temple is managed and maintained by the Temple Trust, the streets and farmlands along with building knowledge and skills of construction and the art of wood carving in vernacular houses are kept alive by the local people. The paper argues an approach to architectural preservation overlooking the significance of both tangible and intangible heritage. Traditional knowledge system of techniques and cultural values along with human efforts has shaped the landscape that we see today. This inhabited cultural landscape is dynamic rather than in a fixed state as people live here and pilgrims visit it. Such landscapes need a more holistic and comprehensive framework for conservation which integrates architectural monuments, shared spaces like roads and apple orchids because of its association with people, Wood Carving, and other forms of the Cultural Landscape. Such framework can be obtained by understanding the cultural habits and rituals and beliefs of the people, traditional architectural design vocabulary which shaped the settlements and the buildings and intimate knowledge of site geography and climate that shaped and sustained the settlements.
\end{abstract}

Keywords: architecture preservation, Bhimakali temple complex, cultural landscapes, cultural heritage

\section{Introduction}

Himachal Pradesh, a state in Northern India, also called the land of Gods, is famous for its enchanting landscapes and exquisite buildings ranging from modest homes to complex towers and palaces, which come out organically from the landscape (Dave, Thakkar and Shah, 2013). One such example of a remarkable temple is the Bhimakali Temple Complex, which lies in a small town of Sarahan. The study area consists of the temple complex, the houses nearby it and the agricultural lands. They all form a landscape formed by the virtue of mankind, given the constraints of the nature. The site is huge and has a population of two thousand people, along with one million people visiting the temple annually. The landscape holds cultural significance as it has various layers of political and religious meaning. The built structures i.e. the temple

(C) AesthetixMS 2018. This Open Access article is published under a Creative Commons Attribution Non-Commercial 4.0 International License (http://creativecommons.org/licenses/by-nc/4.0/), which permits non-commercial re-use, distribution, and reproduction in any medium, provided the original work is properly cited. For citation use the DOI. For commercial re-use, please contact editor@chitrolekha.com 
and the houses, are examples of a distinctive indigenous architecture which needs to be conserved. The paper argues that not only the built structure but the whole study area, the holistic landscape, shall be conserved. Also, it talks about the approach to conservation as the conserving the holistic landscape is distinctively challenging.

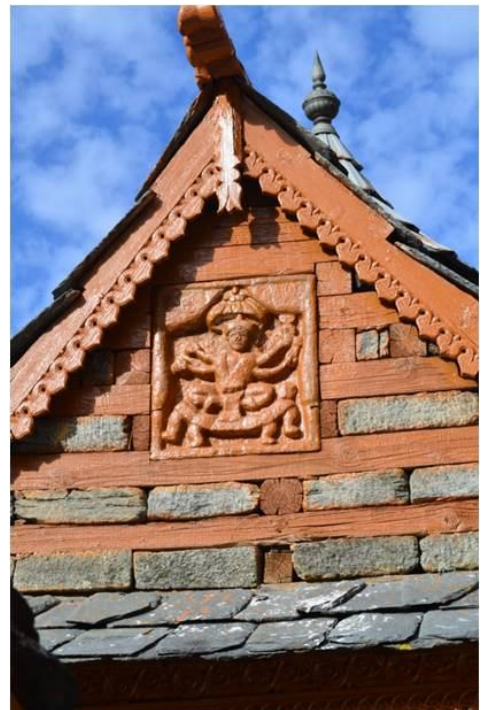

Figure 1. A relief on wood depicting Goddess Kali on one of wall of the temple (Source: Author)

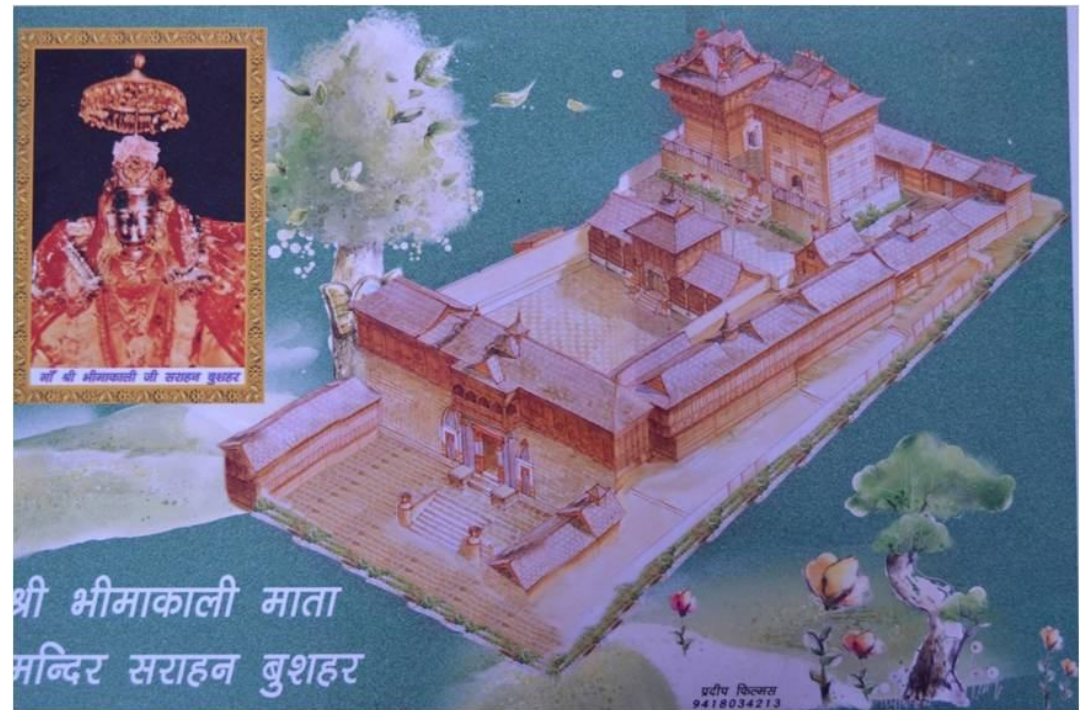

Figure 2. Image on the poster on the streets of Sarahan showing the view of the temple and the idol (Source: Author)

\section{Description of the study area}

Sarahan is situated at a distance of $184 \mathrm{kms}$ on the Hindustan-Tibet Road from Shimla via Rampur and Jeon. The road passes through harsh terrains and is tiring but is very scenic. Every turn on this road opens a new vista-point for one to see as far as the eyes may go. As one reaches atop mountains, a vast panorama of unending mountain ranges is revealed, with the silver Satluj running at the bottom of the gorge. The charm of the place has continued to attract people since the ancient times. The layered history of Himachal Pradesh reflects how the landscape has accommodated waves of migration of people from different direction who were sometimes in pursuit or being pursued, for their faith or fortune. This has created layers of socio 
cultural traditions, which are visible in the architecture and spatial practices of the local communities (Dave et al. 2013).

Since hill people have not yet been much influenced by the industrial and technological growth of the cities and since a vast majority of them still continues to live on primitive modes of agriculture and allied crafts, they are a natural believer and hold strong belief and faiths in natural and supernatural powers (Vaidya, 1997). This has made people very religious and because of this, places of worship or temples, which they believe, where God lives on Earth becomes a crucial place. Thus temples receive high importance as displayed by its architecture and also by the significance which it holds in the lifestyle of the hill people.

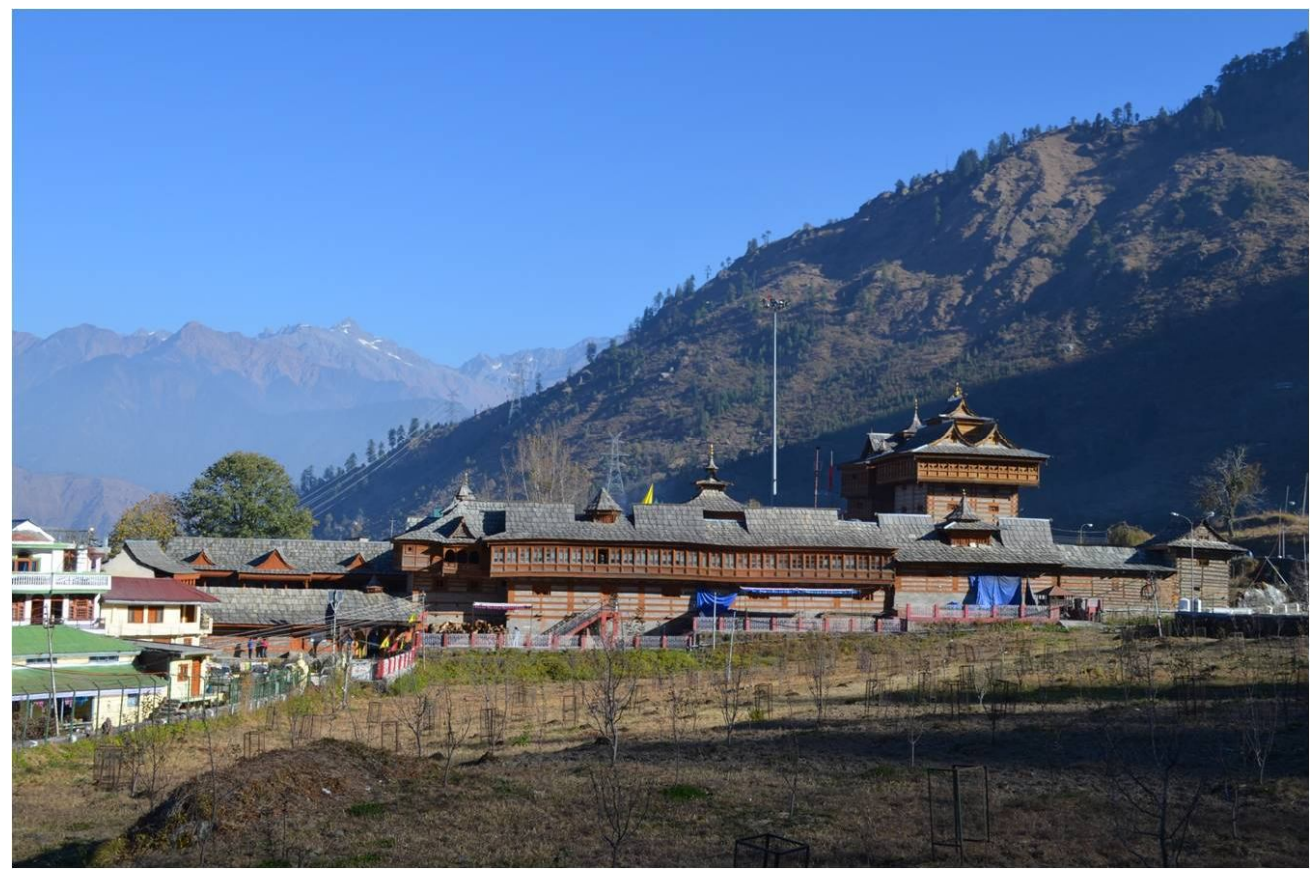

Figure 3. The temple complex dominating the neighbouring settlement, with apple orchids in the foreground (Source: Author)

The traditional Hindu explanation for the significance of the Bhimakali temple is that it was formed from the left ear of the Goddess Sati, who was a previous incarnation of Kali. When Sati's father Daksha, insulted Shiva, Sati's consort, by not inviting him in a feast, she gave up her life. To prevent the mourning Shiva from going mad with grief over Sati's body, Vishnu cut the body to conceal it from Shiva's view (Charak, 1979, p. 119). The parts fell on the earth. These sacred sites where Sati's parts fall are called Shaktipith and links the Goddess with the Earth.

The Bushahr family, who created the temple, claims that they were the descended of Sri Krishan of Hindu Mythology. Charak (1979) explains that Pradumna, grandson of the deity, was said to have journeyed from Vrindavan to Rampur, where he married the daughter of the ruler, Bavasadev. He killed Bavasadev and took the Kingdom for himself. The king built a palace for himself at a strategic location, guarded by hills and in his palace, built a tower temple shrine. He was an ardent devotee of Goddess Bhimakali Ji, who was the presiding deity of the ruling family. He dedicated the temple shrine to her. The temple was inaccessible for people until 1963. 


\section{Methodology}

The methodology employed in the research is the observation done on the field and analysis of secondary data available. Field observation was used to create basic drawing of the temple and its surroundings which provides the physical layout of the space. Various architectural details, people performing socio- cultural activities were sketched, photographed and documented. The local people were interviewed to get an understanding of general atmosphere, expression of feelings, as well as to understand the aspects that would be culturally relevant within the site. During the interaction with people the cultural heritage of woodcarving and indigenous architecture style came up. These were examined and documented through photographs in order to illustrate the manifestation of cultural heritage in the physical form of the cultural landscape. Secondary sources like the existing research on the construction technique of the houses and temples of Himachal, archival data on the history of the temple and the growth of settlement pattern, and articles on Internet were used to support the primary research data.

\section{Review of Literature 4.1. Temple Complex}

Approximately 800 years old magnificent temple complex of the goddess Bhimakali stands majestically over a commanding location, higher than the nearby settlements, amidst the apple plantation and creates strong contrast with the Shrikhand peak at the backdrop (Handa, 2001). The setting of the temple itself creates a feeling of the presence of divine. Just like any temple of Himachal, it occupies experientially highly charged site while acting as the nodal focus for not only the community activities but also for the planning and orientation of the settlement (Dave et al. 2013). This temple which once used to be the palace of the king of Bushahra dynasty has a peculiar style and shows traces of Chinese style (Charak, 1978, p. 335)

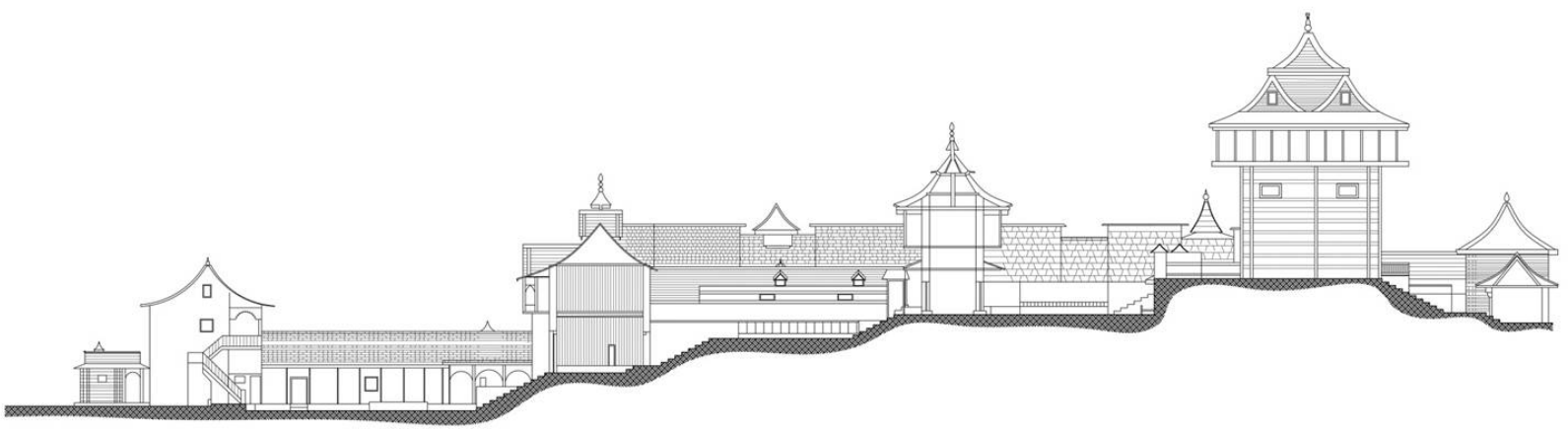

Figure 4: A section showing courtyards placed at different terrace levels. With each elevated courtyard, the privacy of the king increases, depicting closeness to the divine. The sanctum sanctorum is in the tower located at the end (Source: Author)

The Bhimakali Temple Complex has an area of approximately 4500 square meters and is located on a site at an elevation of 2313 metres. The building footprint is in a quadrilateral shape. The complex has the original temple tower encapsulated by linear arrangement of secular and functional buildings. The spatial planning is in such a way that clearly shows hierarchy of courtyards at different levels in ascending order (Handa, 2001)(see Figure 4). The courtyards are separated by secular buildings which are placed laterally.

Raja Padam Singh 1914-1947 AD) was also responsible for the modification and improvement of the complex to a big way. All the buildings in the complex are built in timber- 
bonded stone masonry, peculiar to the mid-Himalayan belt. On the highest terraced courtyard, there is an elevated stone masonry platform where two majestic temple towers stand. These massive towers dominate the entire complex and all other buildings in the locality. The right tower houses the goddess and the left tower acts as a subsidiary building or the bhandar. The towers have gabled pent roof with golden spires on it. Although, the tower-type buildings are not uncommon in the interiors of Western Himalayan region, yet it is only at this place that a pure free-standing tower-type functional temple exists. (Handa, 2001)

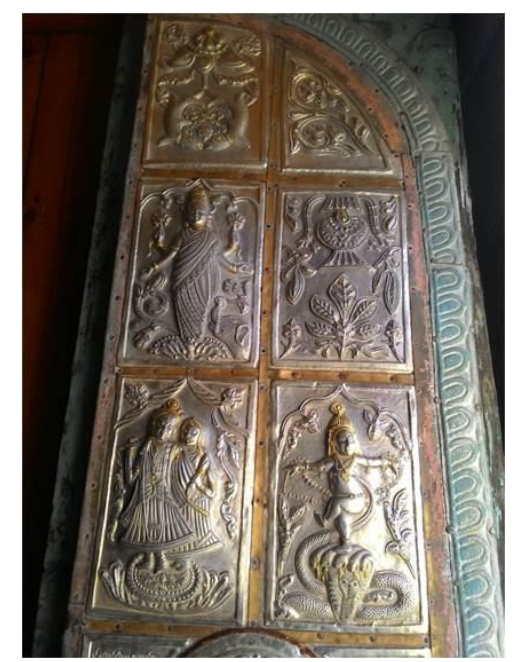

Figure 5: Ornamentation of silver done on the massive doors of the Temple Complex (Source: Author)

In 1905, a massive Kangra earthquake hit the western Himalayas which brought massive devastation in the area (Charak, 1978). By the virtue of the timber bounded four walls of the tower that the tower didn't disintegrate and collapsed but was tilted. In order to control further tilt to the tower, it was encased up to the lintel level of the entrance door in the solid stone masonry platform, with only a small notch for access to the door. The tower to the left has an elaborate superstructure, with an enclosed cantilevered veranda running on all the four sides on the two top floors. The top most verandah is projected further beyond the extended verandah on the lower level. These cantilevered verandas serve as the path used for circumambulations around the chambers of the deities. The outer surface of the vertical wood-work of these verandas is profusely engraved with floral decorations in graceful manner (see Figure 9). The eaves are decorated with heavy ornamented fringes and graceful pendent bells suspended along the corners. The whole structure is covered with a complex roofing arrangement. Pent roofing is provided at the lower level. On it, four graceful gables, one on each pent, are superimposed. The whole roofing arrangement is crowned by a high rising circular canopy, placed at the centre, which tends to counterbalance the visual effect of heaviness to some extent. This complex roofing arrangement is peculiar to this temple only.

In 1930, there was extension and modification in the left tower. Earlier the left tower was covered with simple gable roofing, which made it look dwarfed against the tall tower on the right side. Various other idols of deities are placed in this zone. There is a small platform on the lower level adjoining the right tower. On it, iron tridents are fixed. These tridents are the symbol of the Launkara Bir. There is also a well on the right beside this platform. Patal Bhairav, mythologically regarded as an attendant to Kali (Charak, 1979, p. 116), is believed to reside in it. In the medieval past, the criminals were incarcerated in the well until they died. 
The entry to the temple tower is through a simple passage in the room on the ground floor. The room has a variety of ceremonial artefacts. There is a narrow stairway which leads to the sanctuaries upstairs on the third and fourth floors of the tower. The shrine on the third floor has a richly carved door and a grilled window, through which one may peep inside. This shrine is known as the wedding chamber of the goddess Bhimakali. On the fourth floor is the sanctum sanctorum. It enshrines a finely chiselled and polished image of the goddess Bhimakali as Durga. There are face-images (moharas) and other metal images on the altar in the shrine. There is iron grill across the room separating the Goddess from her devotees. Sacrifice and Bali have been a practise. Buck talks about sacrifices of buffalos during a special mela in honour of Goddess Kali (buck,1979, p. 193)

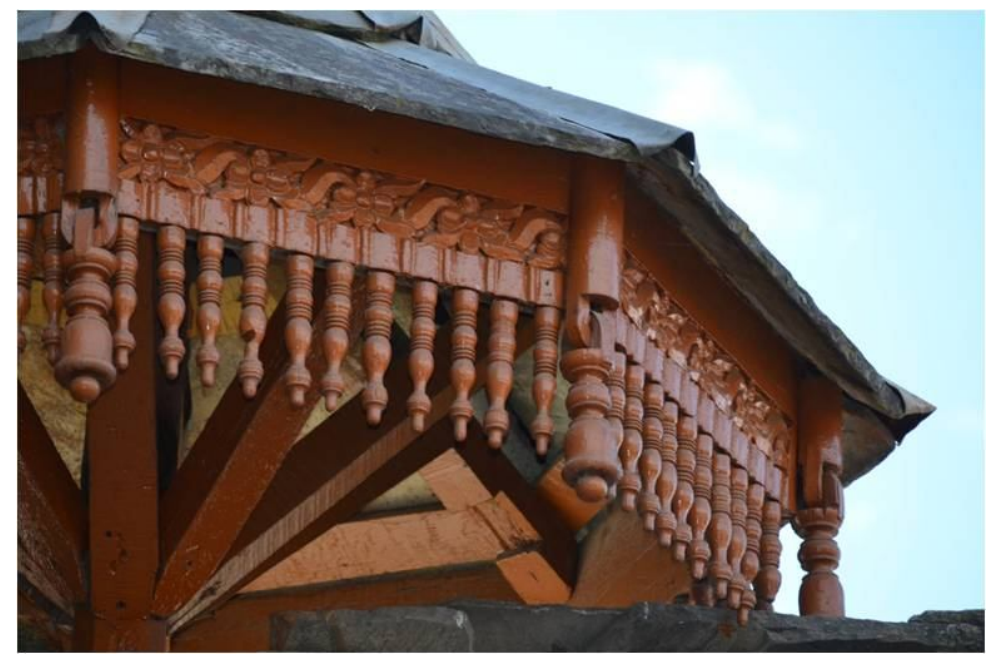

Figure 6: Intricate detailing on the fringes placed at the copula of the temple shrine (Source: Author)

The Bhimakali temple forms a trio of the tower type temples in the Sutlej valley, along with the Kamaru Castle and Castle temple of Sapani. The specialty of these three temples is that they fall in the so called buffer zone of politico-religious expansionism. The buffer zone extends between Sarahan and Pangi Nallah in the upper Sutlej valley, and the style of the temples in this area is highly ambivalent and complex nature of Shakti cult. It is neither the Brahmanical Hinduism of the mainland Himachal nor the Lamaistic Buddhism of the upper Kinnaur, but an interfused form of both, which an overbearing influence of local cults. Downstream of Sarahan, the Vaishnava and Shiva cults predominate, and in the area upstream of village Kothi in Kinanur, Buddhist is the exclusive religion of the people. But Bhimakali temple is the only one which is free standing pure tower type. It is also the latest one in the trio as reflected by the enormous amount of woodcarving present it. The religio-cultural background of this buffer zone is not only essential to understand the genesis of Shakti cult in this area but also to trace the development of distinctive tower type temple architecture, characterized by a castle like structure. The castle like structures would establish that these tower edifices have, beside the sanctuaries, also remained important citadels of authority. On the other hand, the other temples of Shakti like Bhimakali at Kafor and Shakti at Rakcham, barest of political significance, remained single storey structure but imposing (Handa, 2001).

\subsection{Settlement Pattern}

Human settlement being an integral part of cultural landscape follows a certain evolutionary cycle, they do not appear arbitrarily in space, they develop at some particular places, spread, interact with other system and reflect these cultural; development of any region in a historical 
framework (Harvey, 1967). The commonality among the settlements in Himachal Pradesh is that people have used locally available materials and the construction techniques remain the same throughout. In Sarahan, the settlements are made along the contours on the southern sunny slopes to get better sunlight. The houses are lined along the main street which acts as a primary circulation artery. The Bhimakali temple is accessed along this movement spine. There are narrow secondary streets which sometime end at small open spaces. These open spaces and streets act as an extension of private spaces of houses. Houses have emerged out organically as a part of incremental process of growth of settlements. One of the constraints of designing buildings or a settlement in a hilly region is definitely the topography. The topography and the landform play an instrument role so the location of the houses and open spaces are chosen very wisely. Ideally flat level is used for open spaces for playground and social gathering spaces. The Temple complex also has been built upon a flat land. As closer to the Temple, is closer to God, the relatively larger houses of the rich and politically significant people are placed closed to it. Then there are smaller houses for the local people. The size and placing of houses are thus also affected by the economic and social status of the people in the community. Topography also affects the pedestrian circulation, apart from site selection. The routes both pedestrian and vehicular are dictated by the landform of the area in such a way that there are ample views.

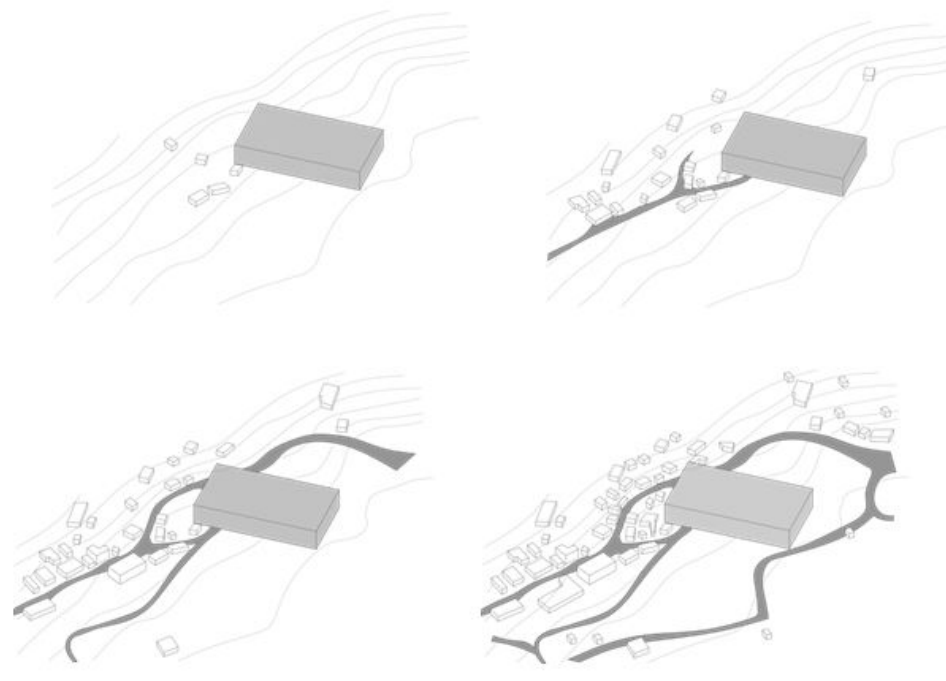

Figure 7: Morphology of the settlement in Sarahan (Source- Author)

\section{Cultural Heritage}

Himachal Pradesh preserves a rich cultural heritage through traditional life of its honest and laborious men and women folk, sacred religious sanctuaries and simple arts and crafts. (Chib, 1977, p. 117) Shashi also says

'The artistic talent of pahari people of Himachal Pradesh is a many sided reality with them. Imbued with the innate desire to add gaiety and colour to their arduous life, the people give expression to their religio- aesthetic urge...'

There is a need to be self sufficient, independent and resourceful, when there are severe environmental and climatic conditions. Weaving and technique of constructions of walls (kathkuni) are necessary to thrive, but arts like Wood carving, metal craft, etc., comes into picture when people become more isolated during the snow season. Such crafts become an integral 
expression of indigenous people. They are often used to depict their lives and beliefs, which are clearly visible in narratives and religious motifs in wood carvings, metal works and stone craft.

\subsection{Kath Kuni Architecture style}

Himachal Pradesh region has major earthquake prone areas (Chandel and Brar, 2010). Buildings are to be designed to resist earthquakes in the region of Saharan. Earthquakes and climate has led to a particular type of regional architecture which share similarities in buildings, cluster formations and settlement patterns (Dave et al. 2013). The construction system is carried on by hereditary mistris (carpenters) who don't have formal education but have acquired the skills from their forefathers. The knowledge is carried to the next generation orally and by hands on experience. Through empirical understanding and subtly evolved indigenous practices, the system has stood the test of time.

In the interiors of the western Himalayan region, good structural stone that can be dressed and chiselled into blocks is rarely available. The ingenious local artisans devised way to use the stone for building purpose by combining it with wood. The technique became popular and came out to be known as kath kuni. It is a combination of two local terms, kath, a dialectic variation of the Sanskrit term kashtth, which means wood and kuni is again a dialectic variation of the Sanskrit term kona, that is, angle or a corner. The term kath kuni thus implies to have wood on its corners or angles. The most common type of kath kuni wall is made by laying apart two square sectioned wooden wall beams longitudinally parallel to define the width of the wall. In order to ensure proper bond between the two, these are dove tailed or lap jointed suitably spaced along the length of the wall. Sometimes these cross joints are placed over the wall beam and secured by driving wooden pegs through the holes made in them. The whole framework so done is known as cheoul. The space between the wall beams is hand packed with stones. Over the cheoul a course of stone is laid dry. This process is repeated one after the other, until the height of the wall is attained. As the wall rises, the height of the course of stone decreases and ultimately it is only the wooden beams which are stacked up at the top at each other (see Figure 8). This method of non rigid framework and dry masonry helps in dissipating energy during earthquakes and ground movements. This style came up in the fourteenth century.

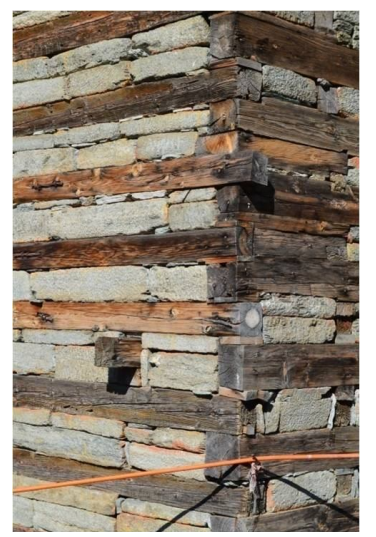

Figure 8: Courses of stone and wood placed to form the wall- Kath kuni Construction (Source: Author)

Some houses built according to this technique are decades and centuries old and still managed to stand. The basic construction system draws upon knowledge inherited from generation to generation and extended over centuries. It is a refined consequence of detailing through gradual empirical improvements into a logical construction system. The style has a distinctive aesthetics of hard and soft materials, warm and cool colours and rough and smooth textures. The materials used are locally available. They are wood, stone and slate. They are 
excellent choices for sustainability and performance. The wood used is generally of Deodar (Cedrus Deodara). Deodar is very durable and is commonly used for structural works. The forest of deodar has long been associated as adobe of the gods in the Indian myth. Many communities still revere local deodar forests as sacred groves associated with local devatas. Stone is available locally and acts as a good insulator of heat. They are dressed and used in walls. Slates are cut into thin sheets that are used as tiles on roofs. They are generally cut into triangular and rectangular units and are typically placed on roofs in rows with an overlap between them. They reflect sunlight, absorb heat, are frost resistant and provide moisture barrier.mud is often used to plaster walls on the interiors as well as the exteriors.

However, the construction system is gradually eroding with time. With upcoming new materials, steel, concrete and construction technologies, the indigenous practice is endangered (Dave et al. 2013). The construction system is structurally resilient, takes low efforts and skills to build and maintain, is climate responsive, and is sustainable by the use of local biodegradable materials and reusing it. Not only this, the cultural heritage associated with it is equally important. It can be a beneficial and benign tool in the search for peace, communication between different people, sharing of common values and respect for cultural diversity (Bond and Worthing, 2016, p. 53).

\subsection{Art of Wood Carving}

Thakkar (2004) very truly says that the artisans of the past 'understood the fundamental principles within their surroundings and nature, and transformed them into a "physical reality". It is similar to a mirror which reflects customs, rituals and the belief-systems of society. Along with this, the harsh climate and isolation of the mountains has made people hardworking, cooperative and openly sharing. Some regions are completely cut off from other communities and villages for long period of snow, which has encouraged artistic activities like woodcarving, weaving, etc. Each of which have highly refined aesthetic sense which serves storytelling and expressive approach of the life of local communities (Dave et al. 2013). The art of Woodcarving along with various other arts were directly driven by religion. The artworks represent with singular force what the artist saw within himself and what a devotee, or a layman wanted to look at. There exists a high affinity between the art and culture in the region in which it was produced (Goswami, 1981, p. 286). The folk art of Woodcarving was used to express the culture, motifs were abstraction based on nature, spiritual awareness or the replication of pattern found in natural fauna and flora (Thakkar, 2008). In the Bhimakali Temple Complex, during the reign of Raja Padam Singh (1914-1947 AD) of the erstwhile Bushahr state massive and intricately carved doors were made (see Figure 5). It depicts various Hindu gods and goddesses, in different panels, along with floral ornamentation. It is also one of the finest examples of craftsmanship of the local and Kinnauri silversmiths. Most of the architectural elements, however small are used for carving -hanging pendants along the roof edges, locally called jhalar (see Figure 6), motifs on wooden panel on walls and balconies, door frames and windows. Apart from religious motifs, there are abstract geometric and natural motifs (see Figure 10). Sometimes the motifs are stand alone and sometimes they run continuously on a frieze or panel. The technique used is mainly relief carving, which are used in panels, entablature, friezes and other planar surfaces. Sculptural carving is also used in columns, door frames, hanging pendants, beams and studs. 


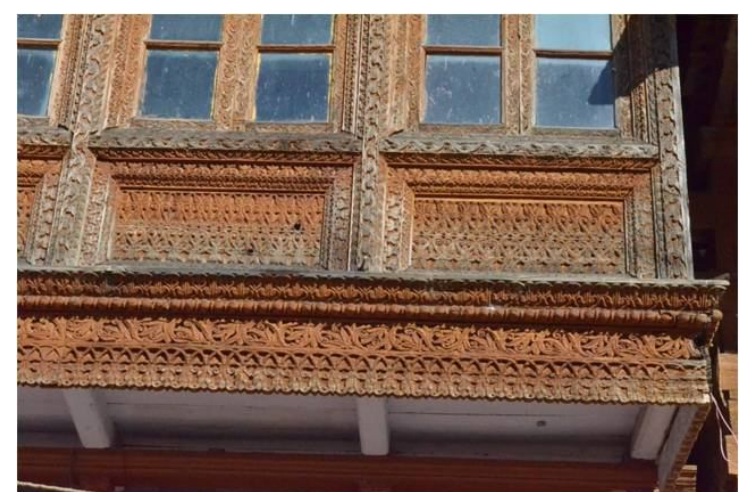

Figure 9: Intricate Wood Carving Details on the walls of the fourth storey of the temple tower (Source: Author)

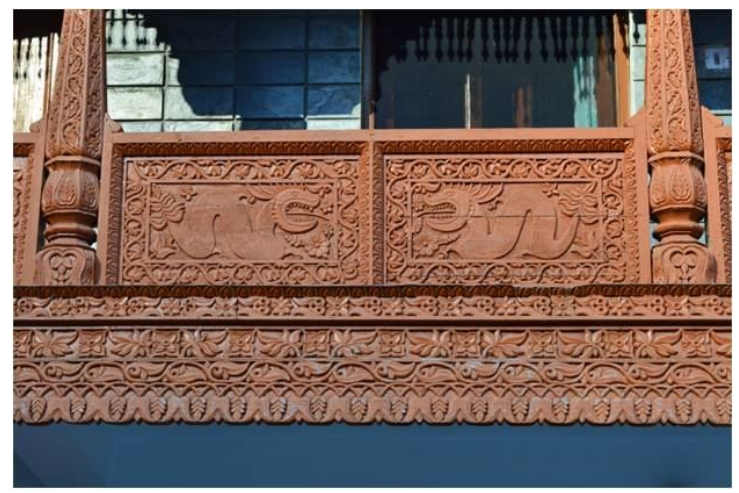

Figure 1o: Wood Carving Details on the parapet wall of the temple courtyard. The wall shows a motif of Dragon, highlighting the tibeten influence on the temple (Source: Author)

\section{Discussion: Cultural Landscape}

Landscape appears natural but also has some kind of cultural association. This is because they are directly or indirectly affected by human action or perception. Rana explains "cultural landscape" does not mean a special type of landscape; instead, it reflects upon a way of seeing landscapes and associated attributes that emphasizes the interaction between human beings and nature over time - maintaining existence-continuity-transformation and transferability' (Rana, 2017). The attributes which he talks about are the indigenous ways of sustaining life, which are found over the years by empirical methods. An attribute could be a ritual practiced since time, a daily activity, building design, settlement pattern, construction style or agriculture. They appear very ordinary but are a result of deep understanding of the physical surroundings. As Taylor (2014) adds-

'We are surrounded by the landscapes that people have settled, modified, or altered over time. These landscapes are cultural landscapes, the everyday landscapes which surround us and in which we conduct our activities. They are the result of human intervention in the natural landscape and present a record of human activity, human values and ideologies. In this way they do not simply represent physical changes brought about by human intervention. They also represent evidence of material culture manifested in the landscape and thereby reflect human relationships with our surrounds. They are an inextricable and coherent part of our intellectual and cultural background.' 
The case of Bhimakali Temple and its surroundings is no different. The indigenous buildings and their making has evolved by a way of empirical practices from local resources and responds to contextual demands directly and effectively (Dave et al. 2013). Not only the buildings, the spatial planning of settlement, formulation of roads and streets and the agricultural lands have been thought of to work, so as to sustain life in severe conditions. Largely all the consideration of physical, social, political, economical, ideological and ecological aspects of the landscape comes into the picture. There are a huge number of connected dots in the landscape of the study area. There are roads, steps, boundary walls, which guide the human movement (see Figure 12). The location and planning of houses, local shrines, shops, gardens and orchids appear trivial but is placed very efficiently for the comfort of the people. It helps us to study the inter relationship among the architectural, urban and landscape features of the context, shaped by the community. There is a network of interconnected systems of pedestrian routes and arrangement of houses and other utilitarian areas. This network is not only functionally well designed but is also aesthetically appealing by bringing the best out of the land, given the difficult terrain to deal with. This brings the various urban design principles used in the area. The circulation spine takes into account the view shed zones, vistas and panoramas of the topography, and creates various viewpoints on the route, thus making journey more enjoyable. Conservation of such area requires measures which are different to that of a historical building. Simply preserving the temple and few houses won't bring justice to the well designed landscape.

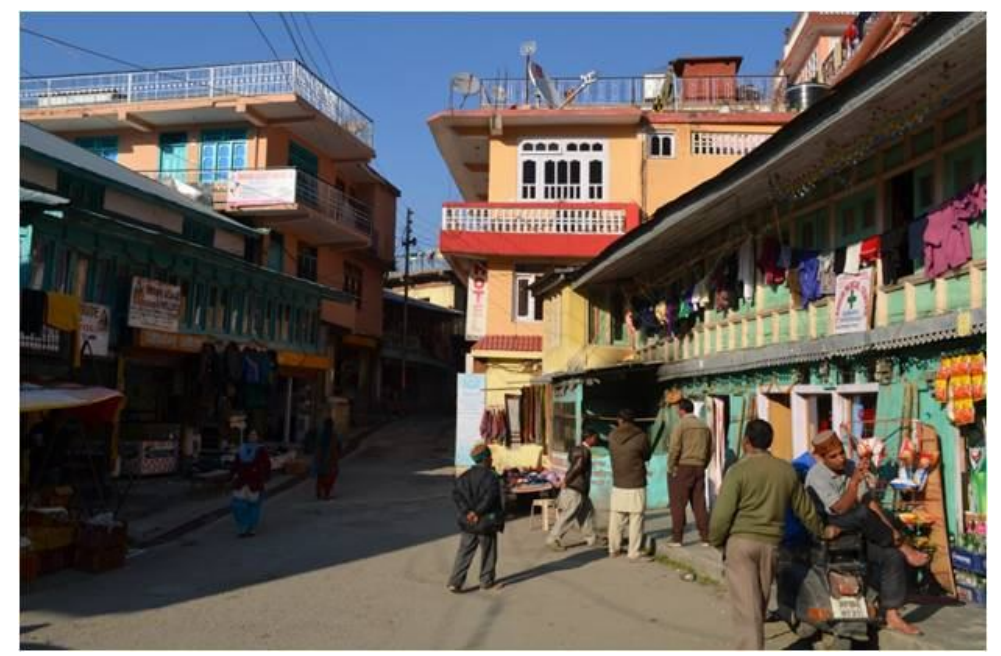

Figure 11: Street which acts as the pedestrian circulation and activity spine of the area. People sit or stand in the sun while doing daily chores (Source- Author)

Another reason why the conservation approach of the site shall be different from any other conventional method is that it is dynamic in nature. In the landscape, human visits, dwells and lives. Human beings are as important in a landscape as vegetation and fauna. As human inhabit spaces and work there, they also become an integral part of the landscape. Another user group is the devotees, who visit the temple in large number. They are a true testimony of the religious significance of the temple, locally and nationally. Devotees offer prayers with flower and food offerings in the temple and other smaller shrines. As festivals come, there are religious rituals along with dances and cultural events, which add a different tone just for a few days. Even the rituals of the people have changed constantly over time. Right from human sacrifice in the medieval times to today, there are changes in ideologies as well. Human activities of the people also play a major role. People begin their day by visiting the temple early morning, then engage 
them in their work. The streets also begin to work from early morning until early evenings (See Figure 11). Bewitched by the beauty, Randhawa (1974, p. 157) mentions

'In spite of intensive cultivation, the number of trees left uncut is large and their crowns shown under the light of the rising sun. Carefully terraced fields, in which potatoes grew, spoke of the industry of the people. These terraces were built by people shifting stones and piling them on the embankments and represent the toil of many generations. Some of the terraces are irrigated by tiny channels, fed by springs. Most of the farm work with the exception of ploughing is done by women. The whole day they are busy cutting grass and carrying home bundles of fuel.'

Most of the people perform agriculture as their main occupation. Especially Horticulture, because a variety of topographic scenes and appropriate soil and climatic conditions. It also provides better and maximum use of land by checking soil erosion and uplifting the economic condition of farmers (Chib, 1977, p. 61). Apple, olive, peach, pear, etc used to grow in wild form. Grafting was introduced to get super variety of fruits. Apple orcharding took the lead in this field (see Figure 3 ).

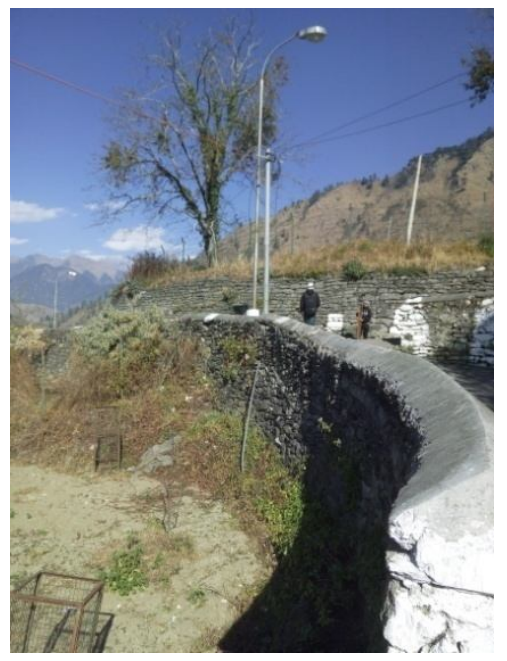

Figure 12: Meandering circulation routes built according to the landform of the region, beneath the cultivation areas (Source- Author)

The world has recognized the heritage value of lived in cultural landscapes represented by the distinctive character created by the local time- honoured traditions that shaped the landscape and sustain the culture and way of life (Mitchell and Barrett, 2014, p. 6o). In 1992, the UNESCO World Heritage Committee recognized three categories of cultural Landscapes. One among them is the organically evolved landscapes (Category 2). These are the result from an initial social, economic, administrative, and/or religious imperative and have developed its present form by association with and in response to its natural environment. Such landscapes reflect the process of evolution in their form and component features. Sub Category of it is a continuing landscape, which retains an active social role in contemporary society and is associated with the traditional way of life, and in which the evolutionary process is still in progress (UNESCO).

There are other reasons demanding for different conservation approach as well, like vegetation and natural resources. The vegetation changes with seasons. Because of the virtue of the extreme climate, there are rains and heavy snowfall. Thus the landscape changes colour wildly during different seasons. The landscape has evolved constantly from the historic period and still continues to evolve daily, seasonally and annually. Such a landscape requires different approach. Sinha also mentions the rationale of a different approach by stating "A landscape cannot be 
delimited to a specific historic moment and cannot be stabilized with fixed forms and meanings. Instead it is a dynamic and interactive environment, which is both, a physical entity and an ongoing process, a dialect of intangible and tangible heritage" (Sinha, 2007). Here the intangible heritage is the belief system. It incorporates traditions which gets transferred from one generation to another, after that these interact with the material world and form the tangible aspect. The belief system encodes and reflects relationship between people and the landscape, and between groups of people in the public (Dave et al. 2013). These two hence creates heritage of the place. The most prominent feature of the visible landscape, are the temple complex and the traditional houses, but even that has intangible heritage with respect to the traditional design vocabulary, which is simply a portrayal of nature and the building skill which is implemented in it. An intelligent response to severe climatic conditions and earthquake resistance was crucial for the sustenance of the settlement. The knowledge concerning the use of materials and techniques for the construction of a building is extremely crucial. Similarly is the case of orientation and planning of streets and buildings to attain human comfort. This knowledge had to be passed to generations orally. This constituted the intangible aspect. Also, in the architecture of temple and even the huge dwelling of wealthy people, ornamentation by carving in wood is important. Wood carving is another intangible heritage which is passed on. All this have shaped the landscaped and manifested the layout of the historical layout with the most intricate details.

\section{Conclusion}

Conservation or preservation of such sites needs special considerations. A broader framework is required as the site is dynamic and is used by different user groups, including pilgrimages, tourists and the local people. The association of the landscape has also created "intangible heritage" which needs special attention. The site has multiple layers of religion, culture, politics and ecology, over a substantial period of time. The question is to balance historical heritage with the living community. There are many aspects to it, one is the reconstruction of the material fabric of wooden and stone monuments and buildings, roads, etc. The other aspect is the value associated with the history and material legacy.

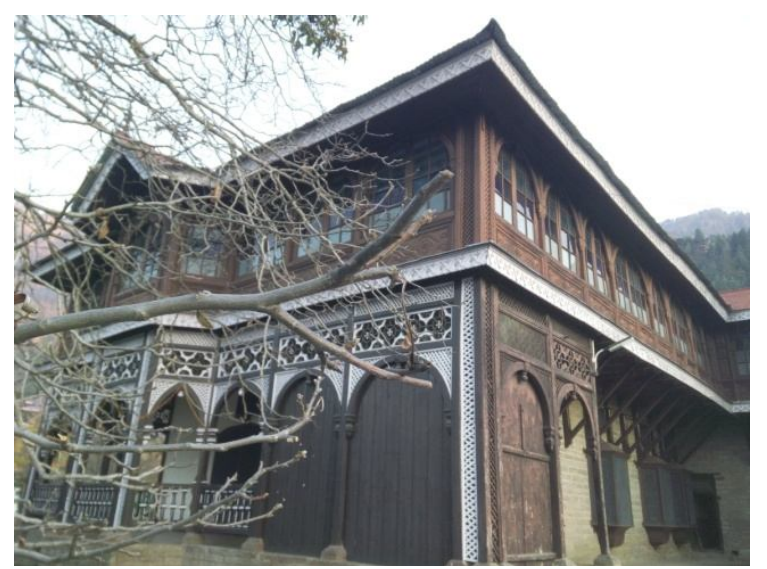

Figure 13: Building along the main road, built in colonial style (Source- Author)

The temple complex is currently managed by the Sri Bhimakaliji Mandir Trust Rampur Bushahr, who manages and maintains the temple, along with 12 other historically significant temples, by the money donated by the devotees and tourist. Because of the exclusive focus on just the architecture of their buildings, the relationship between the temple complex and the site is completely neglected. Similar is the case of each singular house where the owner of the house is 
the stakeholder. There is little to no relationship among the houses in the area as well as between the house and the site. Since the younger generation prefers to live and work in the city for better opportunities, there are heavy chances that the buildings may get abandoned. Another challenge is the coming of hotels, lodge, rest houses due to increasing tourism in the area, which are built in modernist style paying no sensitivity to the architectural design and material nature of the vernacular architecture of the area. Each stakeholder group has its own interests and user groups to serve. This has led to many heritage features of the holistic cultural landscape to be neglected.

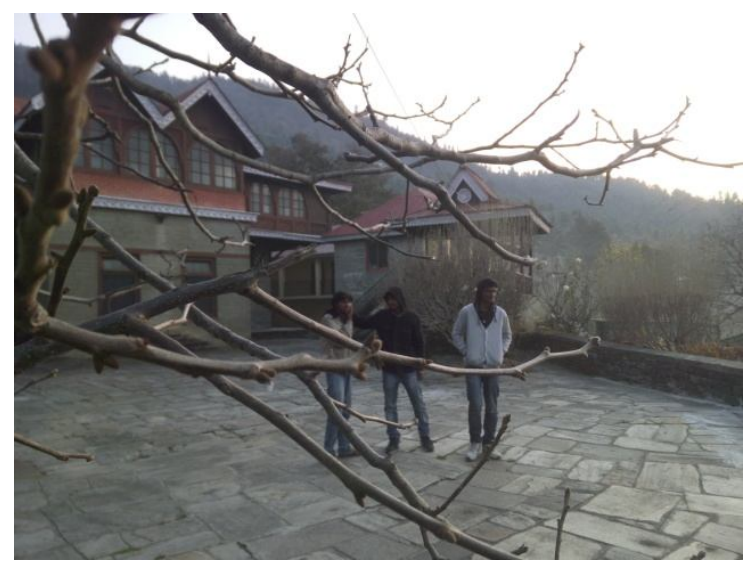

Figure 14: Open spaces in front of the building which is used for socio cultural activities (Source- Author)

Also today people are insensitive to the knowledge of building construction. Lack of people consciousness has been the basic cause for the Himalayan region undeveloped which simultaneously encouraged various problems like the environment, slope failure, soil erosion, floods, deforestation, water scarcities, fuel and fodder (Naithani, 1987, p. 814). As long as people will not be conscious about it, chances of sustainable development are low.

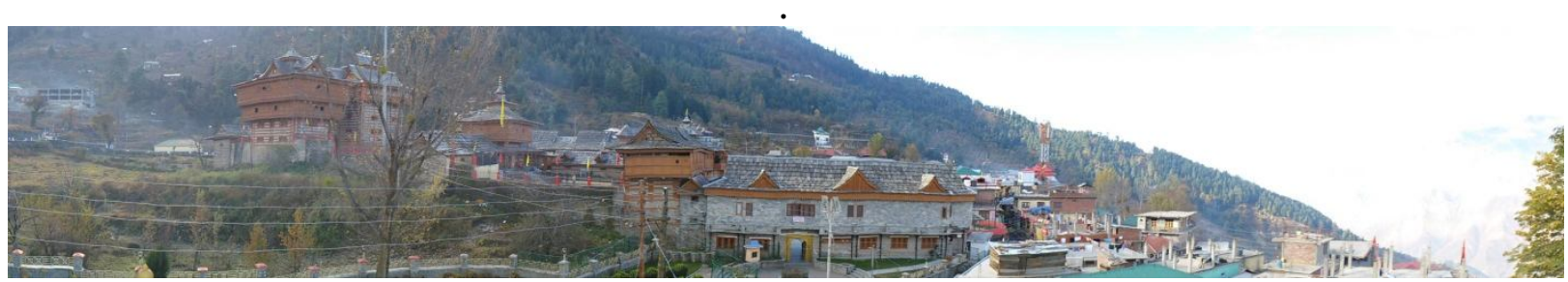

Figure 15: A panoramic view of the Temple complex, neighbouring houses of vernacular design, streets, apple orchids, with the hills on the background

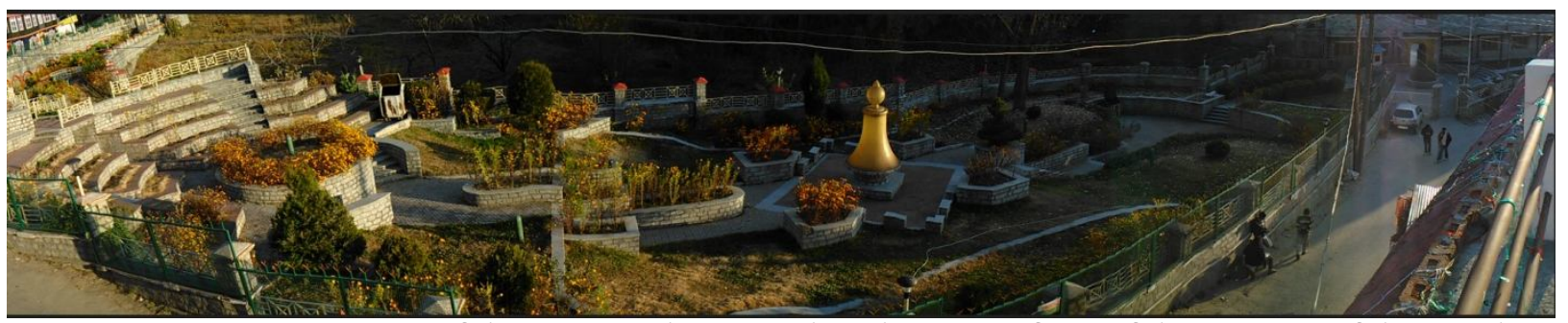

Figure 16: A panoramic view of the open air theatre and garden just in front of the entrance of the temple complex and the street. The theatre is used for variety of events especially during festivals.

A landscape conservation approach and policies is needed to address the dynamic complexity of the landscape and resolve various contradictions implicit to it. One much criticised approach by Archaeological Survey of India is the creation of fences around the protected monument. The moment a fence is erected, a division is created, leading to the isolation of the 
heritage structure from the site and its surroundings. This hampers the holistic view which is a crucial but severely neglected fact in any landscape. This needs coordination and collaboration among the stakeholders to meet the needs of the residents and plan for various other groups, including tourist and devotees. It needs legislative protection and an administrative structure that oversees the landscape planning and management process. There shall be policies governing the location of upcoming buildings in the proximity of the temple, and location of buildings in the view shed zones from roads and major tourist and activity zones, architectural vocabulary of the upcoming buildings and materials and traditional building techniques in the construction of the buildings.

Intangible cultural heritage includes the art of wood carving which a tradition is passed into families. With the younger generation leaving the homes and going into urban areas for better opportunities, the crafts are getting close to extinction. Other Intangible Heritage includes rituals in the temple during festivals and marriages, dances and other performing arts. During festivals like Dusherra, such socio-cultural activities happen only in the courtyards of the Bhimakali Temple Complex. More of such places like chowks could be used for such purposes. Appropriate settings shall be designed to get aesthetically pleasing views of the temple and nature. Degraded landscape features shall be recreated by proper understanding of the cultural sentiments of the people, especially the devotees. Hills and mountains should be conserved properly. Topography, vegetation and water bodies are important ecological characteristics of the hills. The vernacular architecture and settlement pattern were smart enough to well integrate their actions in the landscape in a sensitive manner. But today interventions are rather insensitive which has led to problems due to increased soil erosion, de-silting of river streams and water springs, etc.

The temple complex has the potential to attract tourists that could tax the existing infrastructure of the Temple and its surroundings. Planning and management of the site will lead to community development and will create appreciation for the various intangible cultural heritages of the site which comes only when the holistic view of the temple along with the surrounding landscape is taken into consideration.

\section{Acknowledgments}

The author wants to pay gratitude to the students of Department of Architecture and Planning, Indian Institute of Technology Roorkee, for the documentation of the Temple Complex. No funding was provided for the research.

\section{References}

Bond, Stephen, and Derek Worthing (2016). Managing Built Heritage the Role of Cultural Values and Significance. Chichester: Wiley Blackwell.

Bucks, Edward (1979). "The Hill People, Some Customs and Tradition." In Simla -Past and Present. Delhi: Sumit.

Charak, S. S., \& Charak, S. S. (1979). Himachal Pradesh. New Delhi u.a.: Light \& Life Publ.

Centre, UNESCO World Heritage. "The Operational Guidelines for the Implementation of the World Heritage Convention." UNESCO World Heritage Centre. Accessed October 15, 2018. https://whc.unesco.org/en/guidelines/.

Chandel, V. And Brar, K. K. (2010): Seismicity and Vulnerability in Himalayas: the case of Himachal Pradesh, India, Geomatics, Natural Hazards and Risk, 1:1, 69-84. 
Chib, Sukhdev Singh (1977). This Beautiful India- Himachal Pradesh. New Delhi: Light and Life.

Dave, B., Thakkar, J., Shah, M., \& Hāṇ̦ā, O. (2013). Prathaa: Kath-khuni architecture of Himachal Pradesh. Ahmedabad, India: SID Research Cell, School of Interior Design, CEPT University.

Goswamy, B.N (1981). "Lost Vision: Art in the Himalayan Region Today" In The Himalaya Aspects of Change, 285-295. Oxford University Press.

Handa, O. C (2001). Temple Architecture of the Western Himalayas Wooden Temples. New Delhi: Indus.

Harvey, D. (1967) Models of Evolution of Spatial Patterns in Human Geography, in Models in Geography Chorley, R.S. and Haggett, P. (Eds), London, 549-608.

History, Legends and Myth. (n.d.). Retrieved October 14, 2018, from http://bhimakali.nic.in/en-IN/historylegenda-myths.html

Mitchell, Nora J., and Brenda Barrett (2014). "Envisioning New Cultural Landscapes- Agricultural Traditions and Adaptations." In New Cultural Landscapes, 59-77. Oxon: Routledge.

Naithali, B D (1987). "Himalayan Villages and Their Development." In Western Himalaya Problems and Development, 810-15. Vol. II. Nainital, Uttar Pradesh: Gyanodaya Prakashan.

Randhawa, Mohindar Singh., and Mohindar Singh. Randhawa (1974). Travels in the Western Himalayas. 13762.

Roe, M. H., \& Taylor, K. (2014). New cultural landscapes. London: Routledge.

Ruggles, D. F., \& Sinha, A. (2010). Preserving the Cultural Landscape Heritage of Champaner-Pavagadh, Gujarat, India. In Intangible Heritage Embodied(pp. 79-99). New York: Springer.

Singh, P. (2017, November). Cultural Landscape as National Identity: Illustrating Asia. Retrieved October 14, 2018, from https://www.researchgate.net/publication/321004054_51217_Singh_Rana_PB_2017_17_Nov_Cultural_La ndscape_as_National_Identity_Illustrating_Asia_-_ACLA_Vision_A_Keynote_address_in_the_ACLAAPELA_International_Workshop_Cultural_Landscape_as_National_Identity

S. S. Shashi (1971), Himachal Pradesh, Indian School Supply Depot, Delhi.

Taylor, K., \& Lennon, J. (2011). Cultural landscapes: A bridge between culture and nature? International Journal of Heritage Studies,17(6), 537-554. doi:10.1080/13527258.2011.618246

Thakkar, J. (2004). Naqsh: The art of wood carving in traditional houses of Gujarat: A focus on ornamentation. Ahmedabad: Centre for Environmental Planning and Technology.

Undefined, U. U. (2008). Mātrā: Ways of measuring vernacular built forms of Himachal Pradesh(J. Thakkar \& S. S. Morrison, Authors). Ahmedabad, India: SID Research Cell, School of Interior Design, CEPT University.

Vaidya, K. L. (1977). The cultural heritage of the Himalayas. New Delhi: National.

Excellent Hansda is a student of Architecture, currently pursuing a degree in Bachelor of Architecture in Indian Institute of Technology Roorkee. $\mathrm{He}$ is interested in Visual Communication Design, Narratives and Vernacular Architecture. 